\title{
Miospore evidence for the Carboniferous age of rocks from the Świebodzice Unit (Sudetes, SW Poland)
}

\author{
Kamil PLUTA ${ }^{1}$ and Anna GÓRECKA-NOWAK ${ }^{1, *}$ \\ 1 University of Wrocław, Institute of Geological Sciences, pl. M. Borna 9, 50-204 Wrocław, Poland
}

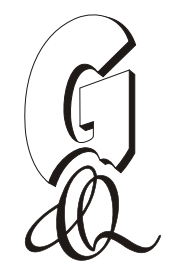

Pluta, K., Górecka-Nowak, A., 2018. Miospore evidence for the Carboniferous age of rocks from the Świebodzice Unit (Sudetes, SW Poland). Geological Quarterly, 62 (1): 120-133, doi: 10.7306/gq.1393

Associate Editor - Grzegorz Racki

\begin{abstract}
The paper provides new results of palynological studies of rocks from the Świebodzice Unit. An abundant Carboniferous miospores were found in rocks of the Pogorzała Formation from the southern part of this unit. These miospores occur in rocks containing also macrofloral and marine macrofaunal fossils, partly reworked, which were usually considered Upper Devonian. Two miospore sub-assemblages of different ages and colours have been distinguished. One of them consists of poorly preserved miospores, dark in colour, which indicate the Late Visean-Serpukhovian age of the rocks. The other sub-assemblage, found only in a few samples, consists of much lighter and well-preserved miospores of the Asturian age. Their presence is considered as a result of stratigraphical leakage. Observation of the miospore colour indicates that the thermal event occurred after the Late Devonian and before the Asturian and the palaeotemperature exceeded $\sim 180^{\circ} \mathrm{C}$. These new data indicate that the geological history of the Świebodzice Unit lasted longer and was much complex than it was previously considered.
\end{abstract}

Key words: Świebodzice Unit, Devonian, Carboniferous, redeposition, stratigraphical leakage, thermal event.

\section{INTRODUCTION}

The Świebodzice Unit (called also the Świebodzice Depression or Świebodzice Fold Structure) is a part of the Central Sudetes (Fig. 1). It is filled with an $\sim 4000$ m thick coarse-grained rocks represented not only by conglomerates but also by mudstones, sandstones, less common marls, and rare limestones. Two rock successions have been recognized. One of them consists of conglomerates. Porębski (1981) divided them into two lithostratigraphic units: the Książ and Chwaliszów formations. The other succession is heterolithic and divided into the Pogorzała and Pełcznica formations (Porębski, 1981). All these rocks are considered synorogenic and accumulated in a fan-delta slope/basin plain depositional system (Nemec et al., 1980; Porębski, 1981, 1984, 1987). Wojewoda (2014, 2016a, b) distinguished turbidites, hemipelagic and pelagic facies in the heterolithic series with olistolites and slumps of older rocks occurring near basin margins.

Porębski $(1987,1990)$ and Wojewoda $(2014,2016 a$, b) assumed that the rhomboid shape of the Świebodzice Unit, bounded by active faults, refers to a pull-apart basin, but these authors presented different models on its development. The

\footnotetext{
* Corresponding author, e-mail: anna.gorecka-nowak@uwr.edu.pl

geological structure of this unit and the age of its infill show serious regional implications, so it is very important that their stratigraphy is thoroughly understood and any controversy explained. Unfortunately, the present-day understanding of the geological setting and stratigraphy is not satisfactory. One of the key stratigraphic problems of this unit is the great lithological diversity due to complex spatial relationships between lithologically diverse rocks. In addition, this area is poorly outcropped and following the continuity of the rock units is usually impossible. Consequently, neither the stratigraphic sequence nor correlation of rocks are obvious. Before 1945, most researchers, including Berg et al. (1910), assumed that the coarse-grained succession was younger than the heterolithic rocks. Teisseyre $(1948,1952,1956 a, b$, 1968; Teisseyre et al., 1957) and Porębski (1981, 1984, 1987, 1990) also agreed with this opinion. The opposite opinion was put foreward by Cramer et al. (1924) who considered the gneiss conglomerates (presently the Książ Formation) as older than heterolithic rocks, currently classified as the Pogorzala Formation. In turn, Gunia (1968) supposed that conglomerates from the Książ and Chwaliszów formations are stratigraphically equal to fine-grained facies with carbonate sediments and were formed in marginal parts of the basin from the late Frasnian to the Tournaisian. Recently, Wojewoda (2014, 2016a, b) presented a new model of the Świebodzice Unit development in which rocks from the central part of this unit, mainly conglomerates, are considered stratigraphically older than rocks in marginal parts. According to this model, conglomerates of the Chwaliszów and 


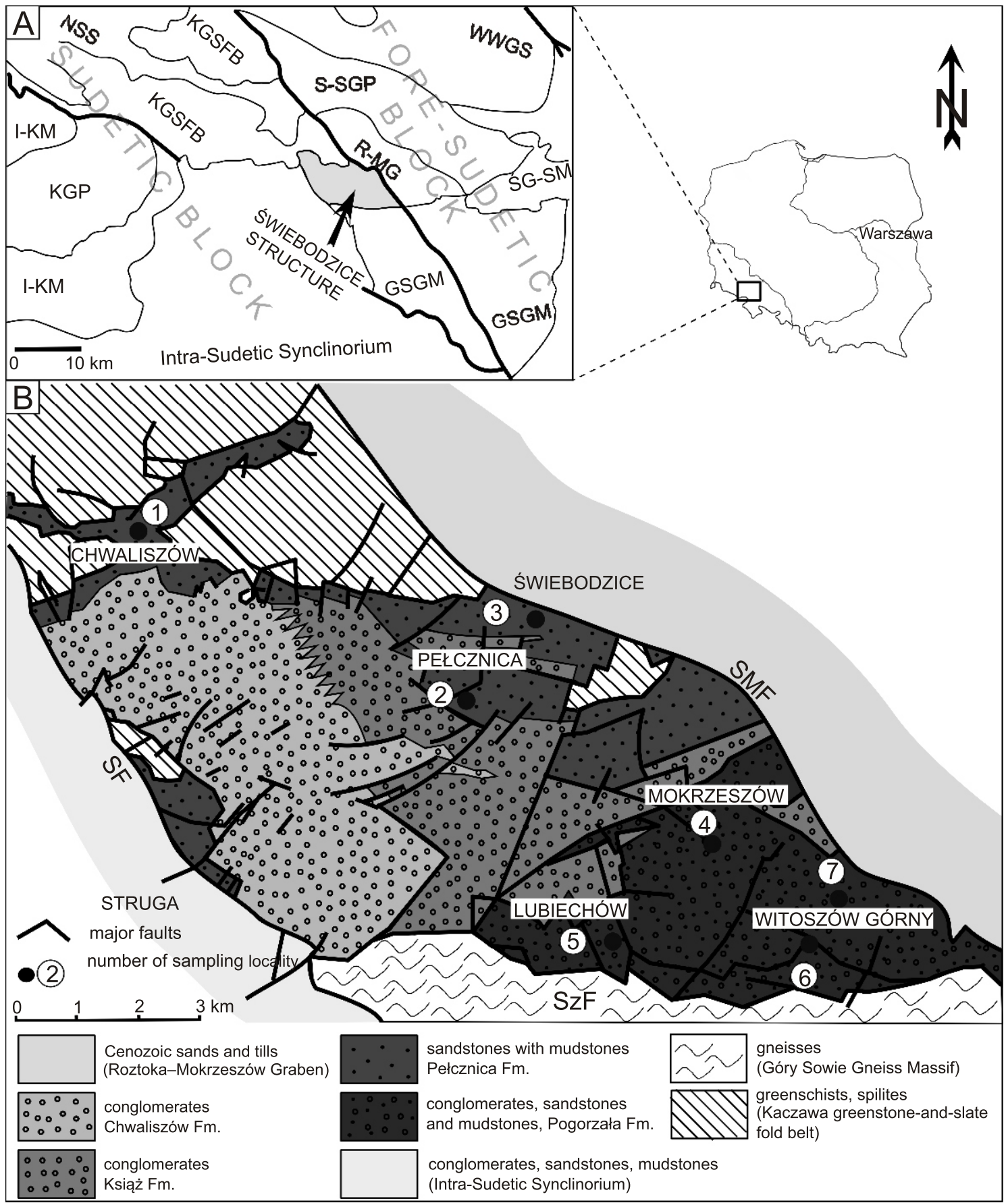

Fig. 1A - geological sketch-map of the central part of the Sudetes (after Żelaźniewicz et al., 2011, simplified); B - geological map of the Świebodzice Unit (after Kaczorowski and Wojewoda, 2011)

A - I-KM - Izera-Karkonosze Massif, KGP - Karkonosze Granite Pluton, NSS - North Sudetic Synclinorium, KGSFB Kaczawa greenstone-and-slate fold belt, WWGS - Wądroże Wielkie Gneiss Massif, S-SGP - Strzegom-Sobótka Granite Pluton, ŚG-SM - Ślęża Gabbro-Serpentynite Massif, GSGM - Góry Sowie Gneiss Massif, R-MG Roztoka-Mokrzeszów Graben; B - SMF - Sudetic Marginal Fault, SzF - Szczawienko Fault, SF - Struga Fault

Książ formations are older than heterolitic rocks of the Pogorzała and Pelcznica formations (Wojewoda, 2014, 2016a, b).

Numerous Devonian and Carboniferous macrofossils of marine fauna as well as Carboniferous macrofloral fossils were found in rocks of this geological unit. These fossils are the main stratigraphic evidence, but they are generally poorly preserved and majority of them are long-ranging taxa. They are unevenly distributed, i. e. many rocks remain without any palaeonto- logical evidence. Additionally, some Devonian fossils are considered reworked as they occur in pebbles in younger rocks and this complicates the stratigraphic interpretation.

Discussion on the stratigraphy of the Świebodzice Unit has continued since the 19th century and the fundamental problem was the Devonian or Carboniferous age of its infill. According to Gunia (1968), the majority of these rocks belong to both stages of the Upper Devonian - the Frasnian and the Famennian, and 
sedimentation finished there in the Tournaisian. This stratigraphic scheme was used for the model of sedimentation presented by Porębski $(1981,1984,1987,1990)$ and it became commonly accepted and, consequently, there was no stratigraphical study for nearly a half of century. The only exception was a palynostratigraphic study by Krawczyńska-Grocholska (1973), who proved the occurrence of Carboniferous miospore assemblages in rocks from the northern part of the Świebodzice Unit. Unfortunately, this interesting conclusion was not taken into account in subsequent interpretations. The recently published paper on Devonian brachiopods (Halamski, 2013) is a harbinger of a new stage of palaeontological and biostratigraphical studies in this area. An attempt to the reconstruction of the Devonian palaeoenvironment was undertaken by Pluta (2016).

The age of rocks of the Świebodzice Unit has fundamental significance in the interpretation of geological setting and evolution of the Central Sudetes. Close proximity of sedimentary rocks, interpreted as Upper Devonian to Lower Carboniferous (Gunia, 1968), and low-grade metamorphosed rocks of Devonian and Visean age of the adjacent Kaczawa Mts. (Urbanek, 1975,1978 ; Chorowska, 1978) is one of the facts difficult to explain.

Another important topic is time relation between clastic rocks of the Świebodzice Unit and gneisses of the Sowie Mts., which commonly occur as pebbles in the former. During all discussions, it has been considered as an axiom that the Sowie Mts. gneisses and their exhumation have to be older than Devonian (Zinkiewicz, 1973; Gunia, 1985). Currently, the final stage of the metamorphic event of the Sowie Mts. block is dated as Late Devonian, precisely at 385-370 Ma on the basis of U-Pb and Rb-Sr data (van Breemen et al., 1988; Bröcker et al., 1998; Timmermann et al., 2000), and this result has been used for geological syntheses covering the entire Sudetes (Mazur et al., 2006).

Numerous miospores were found during recent palynostratigraphical studies undertaken in the Świebodzice Unit. Majority of them is undeterminable due to very poor preservation caused by high thermal alteration. Miospore data from the southern part of this geological unit provided amazing results, as they revealed occurrence of recognizable Carboniferous miospores in rocks interpreted before as Devonian. Two miospore sub-assemblages were distinguished and the older of them consists of hardly recognizable and dark-coloured miospores. Some better preserved miospore specimens indicate Late Visean-Serpukhovian age. The other miospore sub-assemblage consists of well-preserved specimens indicating the Asturian age (former Westphalian D). Their stratigraphic interpretation is not easy and the geological significance of these two Carboniferous dates is discussed hereafter. They appoint a different time frame of the Świebodzice Unit development, compared to the previously accepted opinions, indicating that the geological history of this unit is still unclear and apparently more complicated than it was previously thought. Palynological research appeared to be a perspective method for the study of stratigraphical problems in this area.

\section{MATERIAL AND METHODS}

Palynostratigraphical studies were recently undertaken in the whole Świebodzice Unit (Fig. 1B). Forty-seven samples were taken from fine-grained rocks, mainly mudstones. Samples from the Pełcznica Formation were taken near the villages of Chwaliszów and Pełcznica. Five samples were taken from an outcrop of mudstones near a field road close to Chwaliszów (locality no. 1 in Fig. 1B; N5052'27.56”, E16 $\left.{ }^{\circ} 13^{\prime} 34.53^{\prime \prime}\right)$. Two localities close to Pełcznica were sampled: 5 samples were taken near the ancient yew Bolko (outcrop no. 2 in Fig. 1B; N50 50'52.77', E16 $\left.17^{\prime} 28.01^{\prime \prime}\right)$ and 4 samples were taken near cascade on the Pełcznica River (outcrop no. 3 in Fig. 1B and nos. 44 and 44a of Gunia, 1968; N5051'26.7', E16¹8'41.37'). One sample was taken from mudstones on the shore of Daisy Lake close to Mokrzeszów (outcrop no. 4 in Fig. 1B and no.15 of Gunia, 1968; N5049'28.17’, E16²1'41.71'). The Pogorzała Formation was also sampled near the villages of Lubiechów and Witoszów Górny. The quarry in Lubiechów (no. 5 in Fig. 1B and no. 26 of Gunia, 1968) is located in the Książ Landscape Park, $2 \mathrm{~km}$ south of Lubiechów (N: 5049'2.03", E16'19'48.05"; Fig. 2A), which is the NE district of Wałbrzych. Teisseyre (1956a) considered this place as the centre of the Pogorzała syncline. From this quarry, 19 rock samples for the palynological studies were taken. Samples were taken also from two localities near Witoszów Górny. One of them is the quarry of slate roof tiles (outcrop no. 7 in Fig. 1B and no. 3 of Gunia, 1968; N5049'19.05”, E16²2'57.56”') where 3 samples were taken. Ten rock samples were taken from mudstones from another outcrop in Witoszów Górny (no. 6 in Fig. 1B), located on the left bank of the creek between Witoszów Górny and Pogorzała (N50 48' 57.97', E16 $\left.22^{\prime} 31.29^{\prime \prime}\right)$ in a place regarded by Teisseyre (1956b) as the southern wing of the Pogorzała syncline. This outcrop and the quarry in Lubiechów are described in detail below, as they provided abundant miospore data.

Palynological samples were thoroughly cleaned and then crushed. The first step of their chemical processing was the use of hydrochloric acid $(\mathrm{HCl})$ to dissolve carbonates. The samples were then processed in $40 \%$ hydrogen fluoride. Next each sample was divided into two parts: intended for thermal maturity assessment and palynostratigraphical studies. The Schulze method of oxidation was applied only to the latter samples, and $65 \%$ nitric acid and potassium chlorate were used. After the purification, microscopic slides were made from the residuum. The slides were subsequently analysed using a Nikon Optiphot 2 microscope. Photomicrographs were made using a digital camera Canon PowerShot A640. All slides are stored at the Institute of Geological Sciences, University of Wrocław.

\section{RESULTS}

Rocks from all studied sites yielded miospores, but majority of them are unrecognizable due to very poor preservation caused by the high thermal alteration. The abundant and well-preserved miospores occurred in seven samples of the Pogorzała Formation. They were found in rocks from the Lubiechów Quarry (no. 5 in Fig. 1B) and the outcrop near Witoszów Górny (no. 6 in Fig. 1B) in the southern part of the Świebodzice Unit. The complicated geological structure of rocks occurring in these two locations is worth discussing because it influences the stratigraphic interpretation of miospore data.

THE LUBIECHÓW QUARRY

The quarry consists of two parts, but mudstones suitable for palynological studies occur only in its upper part. Main lithological types are conglomerates, sandstones, mudstones and very rare limestones. The complexity of spatial relations among lithological varieties is shown in Figure $2 \mathrm{~B}, \mathrm{C}$ and $\mathrm{D}$. 

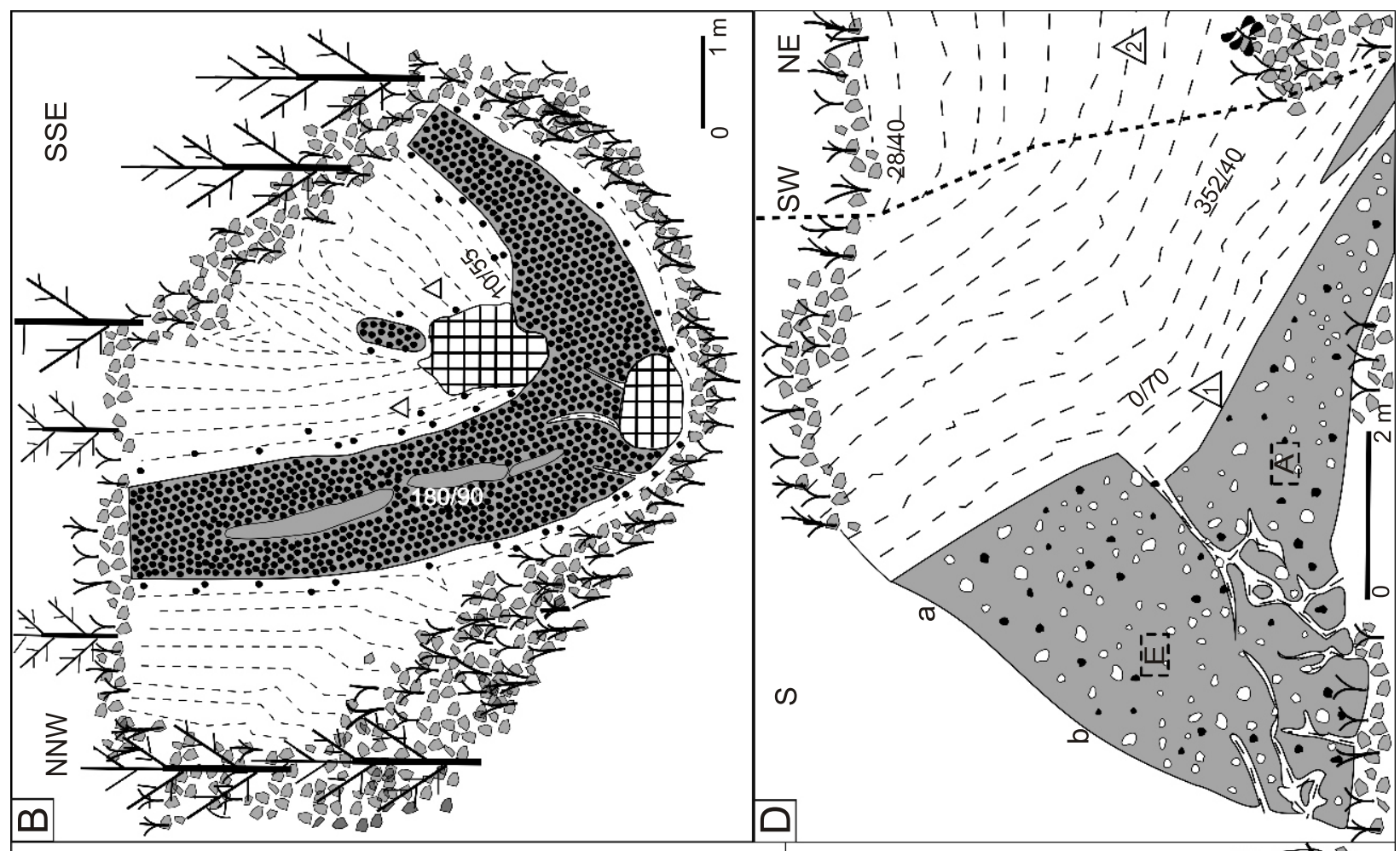

$\frac{\mathbb{2}}{\frac{\pi}{\sigma}}$

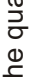

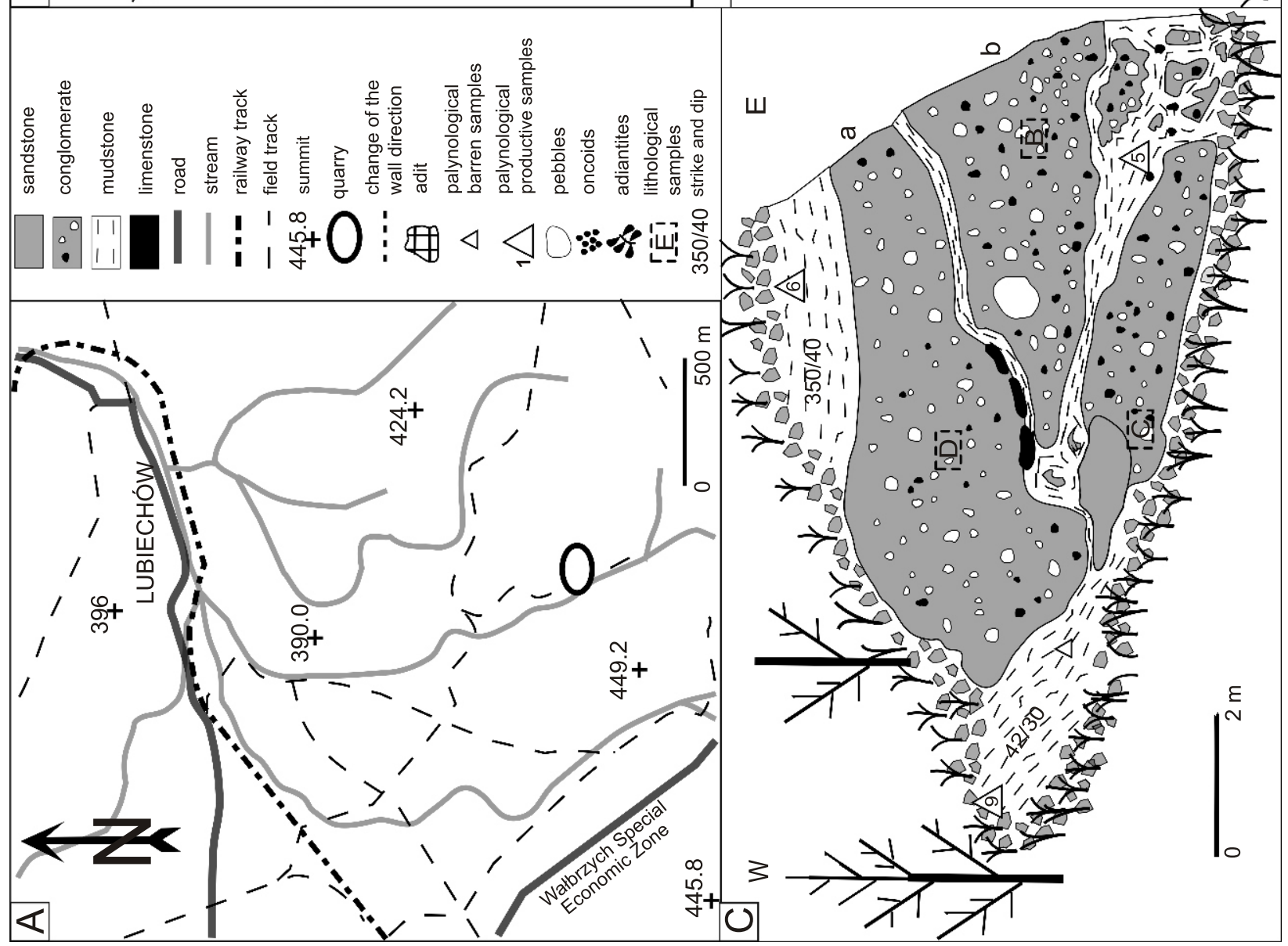


On the eastern wall of the quarry, mudstones and conglomerates form a kind of trough, which is $\sim 5 \mathrm{~m}$ wide (Fig. 2B). The conglomerates are surrounded by mudstones. The bedding in mudstones is variable and masked by frequent cracks and slickensides, but refers generally to the shape of the conglomerate body. Small sandstone bodies occurring as discrete loafs and injections of mudstones, probably forming clastic dykes, occur within the conglomerate body. Conglomerates consist of Sphaerocodium balls - oncoids with Sphaerocodium zimmermanni Rothpletz, also known as Girvanella (Pia, 1937). These oncoids are up to $5 \mathrm{~cm}$ across and occur in the sandstone matrix. They were described by Zimmerman (1911) who considered them Late Devonian in age and syngenetic with conglomerates in which they occur. Schindewolf (1925) agreed that the Sphaerocodium balls are in situ and supposed that they originated in a shallow-marine environment and are related to the crushing of coral reefs.

The northern wall of this quarry is composed mainly of conglomerates with sandy matrix and mudstones (Fig. 2C, D). Small bodies of sandstones and limestones also occur. The bedding in mudstones is concordant with the outline of the conglomerate body, which seems to have a lenticular shape. Conglomerates contain pebbles of different rocks and infrequent oncoids. In addition, mudstones that fill "slits" in the conglomerate body seem to be clastic dykes and contain some sharp-edged blocks of sandstones and conglomerates. Furthermore, several limestone blocks occur in the middle part of the wall (Fig. 2C). They are $\sim 30 \mathrm{~cm}$ thick and occur along the border of the "slit", in one line, attaining $2 \mathrm{~m}$ in length. They are probably fragments of a crushed limestone plate. The present-day arrangement of rock bodies was interpreted by Porębski (1981) as rock record of gravity flow. This author considered the occurrence of conglomerate bodies by the "rigid stopper" mechanism in rocks of sliding character. Wojewoda (2016a, b) supposed that rocks occurring in this quarry are a fossil slump sheet of presumed Visean age.
Gunia (1968) found quite numerous macrofossils of marine fauna in rocks from this quarry: Rugosa corals and Amphipora $\mathrm{sp}$. occur in the conglomerate matrix, where also numerous unrecognizable fragments of brachiopod shells were found. Latter remnants occur also in oncoids. Poorly preserved fossils determined as clams Buchiola palmata and $B$. retrostriata, as well as goniatites Tornoceras auris (Quenstedt) and T. paucistriatum (Archiac et Verneuili) were found in mudstones. Gunia (1968) assigned these rocks to the Upper Frasnian.

An imprint of the Carboniferous fern leaf Adiantites antiquus (Ettingshausen) Stur (Fig. 3) and undeterminable imprints of stems were found during our field work in a mudstone block near the eastern wall of the quarry (Pluta, 2012). Abundant fragments of crushed fossils - stomatoporoids, corals, probably brachiopods and clams - were found in mudstones and conglomerates (Fig. 4). They occur among sharp-edged fragments of rocks and oncoids, and some of them were observed also inside oncoids. The microscopic observations of macrofauna shells or their fragments often reveal presence of very thin lithic sheaths around shell fragments (Fig. 4D, E). This indicates that some macrofossils considered as bioclasts in fact appeared to be lithoclasts (Pluta, 2012) and their occurrence in rocks suggests redeposition. Oncoids commonly occurring in conglomerates, according to a recent model, grew at a muddy bottom in low-energy conditions (Peryt, 1981; Pluta, 2016).

\section{OUTCROP IN WITOSZÓW}

The main lithologic type in this outcrop is represented by dark grey or grey, clearly bedded mudstones with ripple marks and intercalations of sandstones. These rocks are covered by conglomerates containing rounded pebbles of limestones and gneisses (Fig. 5). The loaf-shaped body of well-sorted sandstone occurs in mudstones and its thickness varies from centimetres to a few metres. Sandstones and conglomerates lie

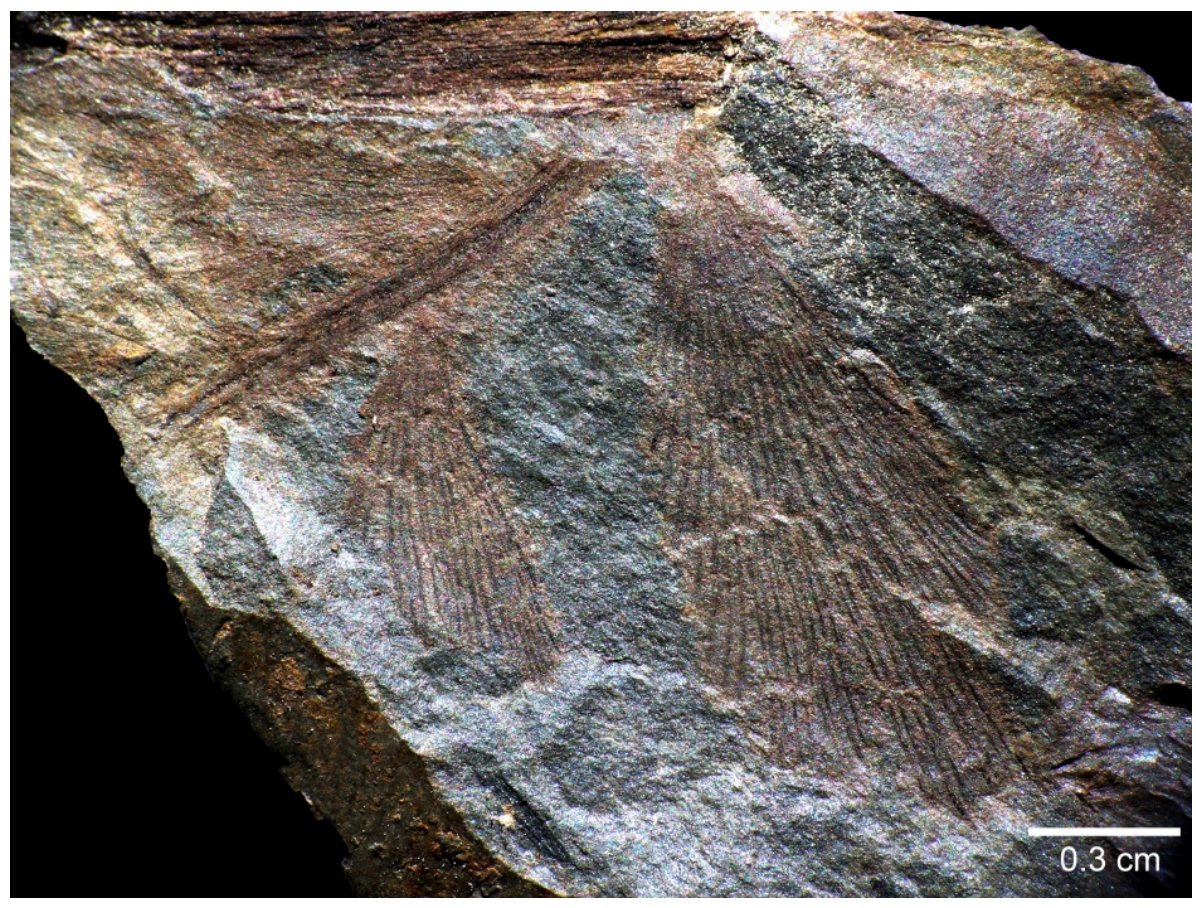

Fig. 3. Imprint of Adiantites antiquus (Ettingshausen) Stur found in a mudstone block in the Lubiechów Quarry (phot. Kamil Pluta) 

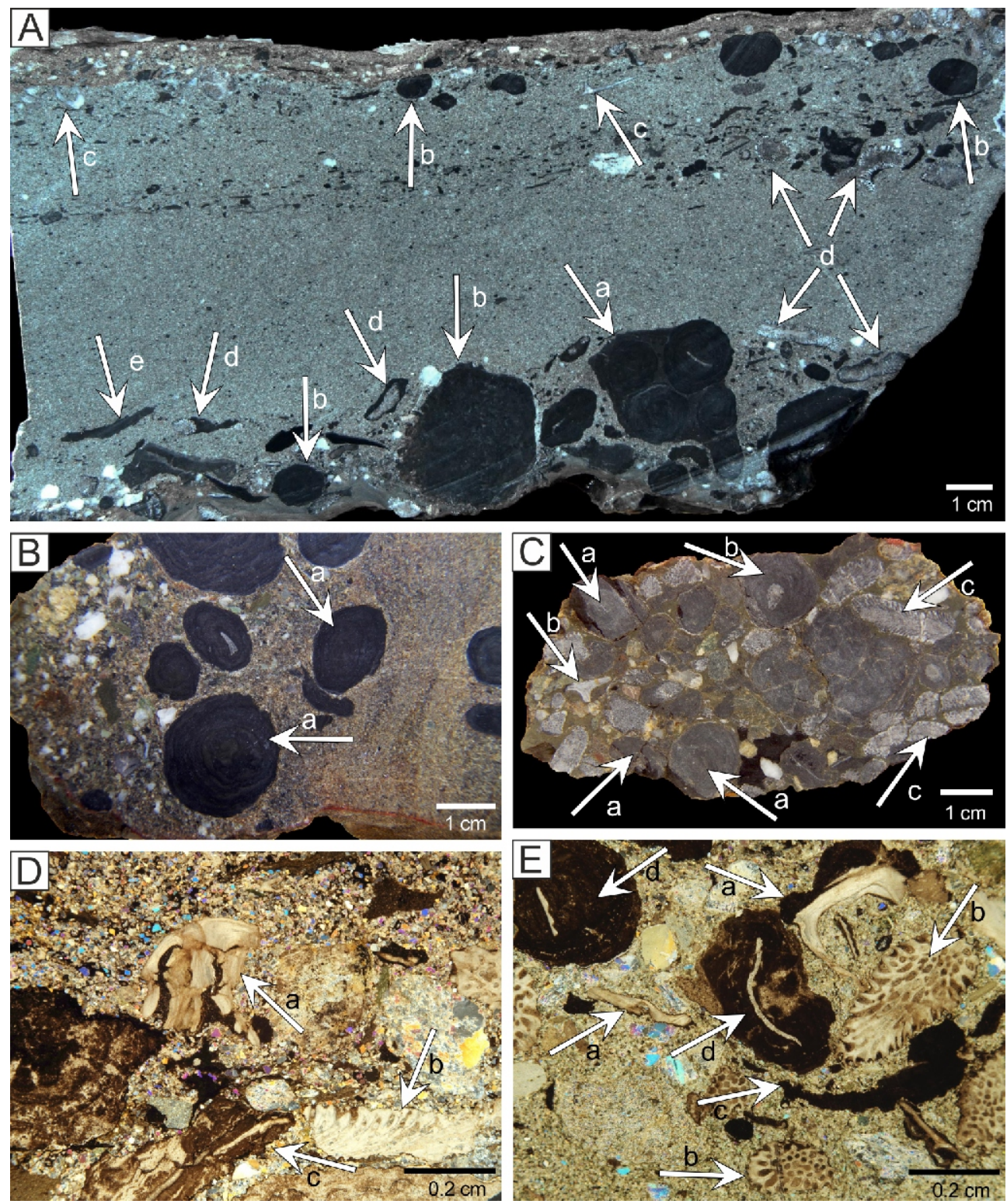

Fig. 4. Record of the fossils redeposition in rocks of the Pogorzała Formation from the Lubiechów Quarry (samples from the north wall of the quarry, marked as lithological samples A-E in Fig. 2C, D)

A - pebbly sandstone, sharp edged lithoclasts of oncoid limestones (a), separate oncoids (b), fragments of brachiopod shells surrounded by very thin lithic sheaths (c), fragments of Amphipora sp. with preserved limestone sheaths (d), fragments of limestones (e); B - pebbly sandstone with oncoids showing preserved internal structure (a); C - compact Spherocodium conglomerate with oncoids (a), fragments of brachiopod shells surrounded by very thin lithic sheaths (b), fragments of Amphipora sp. with preserved limestone sheaths (c); D - pebbly sandstone - thin section in polarized light, fragments of brachiopod shells (a), fragments of Amphipora sp. with prominent limestone sheaths (b), sharp-edged fragments of limestones (c) in the sandy matrix; E - pebbly sandstone - thin section in polarized light, fragments of brachiopod shells (a), fragments of Amphipora sp. with prominent limestone sheaths (b), sharp-edged fragments of limestones (c) in the sandy matrix, oncoids which grew on a thin shell of a brachiopod or a clam (d) 


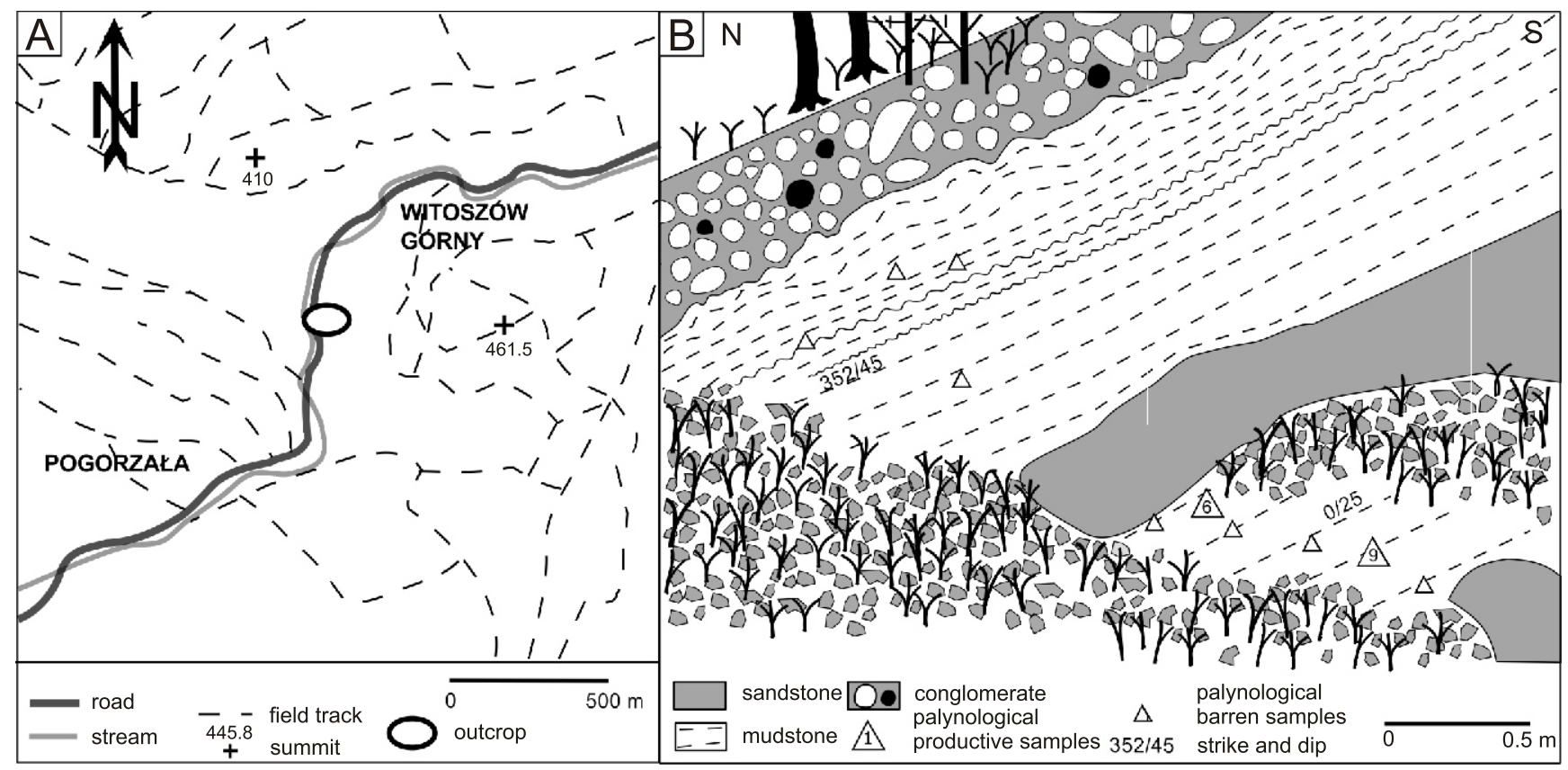

Fig. 5. The Witoszów Górny outcrop

A - location of the outcrop; B - sketch of the outcrop

concordantly between surrounding mudstones. The presence of gneiss pebbles and the analysis of ripple-mark asymmetry indicate that the rock material was transported from the south. Porębski (1981) suggested that these sediments are of gravity-flow origin.

Gunia (1968) described many macrofaunal fossils in limestone pebbles from conglomerates overlying the mudstones. Rugosa corals, stromatoporoids and brachiopod Spinatrypa are found there. Macrofossils in the mudstones are relatively rare, but Gunia (1968) reported occurrence of undeterminable remnants of macroflora and a poorly preserved internal mold of cephalopod Bactrites cf. ausavensis. On this basis, the rocks were assigned to the Upper Frasnian.

\section{CHARACTERISTICS OF MIOSPORE ASSEMBLAGES}

The miospore assemblages determined in productive samples from the Lubiechów Quarry and the outcrop near Witoszów Górny (Figs. 2 and 5) are peculiar. Each of them consists of two miospore sub-assemblages that differ in colour (Figs. 6 and 7).

The sub-assemblage of dark miospores contains dark brown to black, hardly recognizable specimens. The determination of miospores from this group was possible only if the miospore structure was preserved despite its high thermal alteration or the specimen was slightly better preserved. Rocks from the Lubiechów Quarry contained the following genera: Bascaudaspora, Densosporites, Knoxisporites, Kraeuselisporites, Lycospora, Radiizonates Schulzospora, Vallatisporites, and two species: Cingulizonates bialatus ${ }^{1}$ and Rotaspora knoxi. Samples from Witoszów Górny yielded abundant dark miospores and genera Lycospora and Densosporites were recognized among them (Appendix $1^{*}$ ).

The other sub-assemblage consists of light-coloured specimens - yellow-orange to orange-brown. These miospores are better preserved (Figs. 6 and 7) and appeared to be taxonomically diverse, as 73 miospore taxa were determined in this sub-assemblage (Appendix 1). The most taxonomically diverse miospores were found in samples Lub 6 and Lub 9 (Appendix 1). A similar, although not so numerous miospore assemblage, was recognized from Witoszów Górny. The similar preservation and taxonomically comparable composition of miospore data from these two locations suggest that they may be discussed and interpreted together. The characteristic feature of this association is the presence of genera Calamospora, Cingulizonates, Cyclogranisporites, Densosporites, Lycospora, Punctatisporites, Radiizonates, Raistrickia and Verrucosisporites. Some stratigraphically important miospore species include Ahrensisporites guerickei, Alatisporites pustulatus, A. trialatus, Apiculatasporites spinulistratus, Cadiospora magna, Crassispora kosankei, Latensina trileta, Microreticulatisporites nobilis, Planisporites magnus, Reticulatisporites reticulatus and Westphalensisporites irregularis. A fairly large variety of miospores from the Monoletes group was found. It includes relatively numerous specimens of the Laevigatosporites and Punctatosporites, as well as some less common specimens of Torispora and Thymospora. The composition of the assemblage is complemented by pollen grains, mainly of the Florinites type, but they are not abundant (Figs. 6 and 7; Appendix 1).

\section{STRATIGRAPHICAL INTERPRETATION}

The miospore data from the Pogorzała Formation, considered before as Devonian (Gunia, 1968), clearly indicate their Carboniferous age. The coexistence of two miospore sub-assemblages of different colours suggests that this miospore assemblage is mixed. The analysis of taxonomic composition and the stratigraphical ranges of miospore taxa confirm this supposition, as these sub-assemblages differ also in stratigraphical position.

* Supplementary data associated with this article can be found, in the online version, at doi: 10.7306/gq.1393

${ }^{1}$ Full names of determined miospore species with names of creators are listed in Appendix 1 


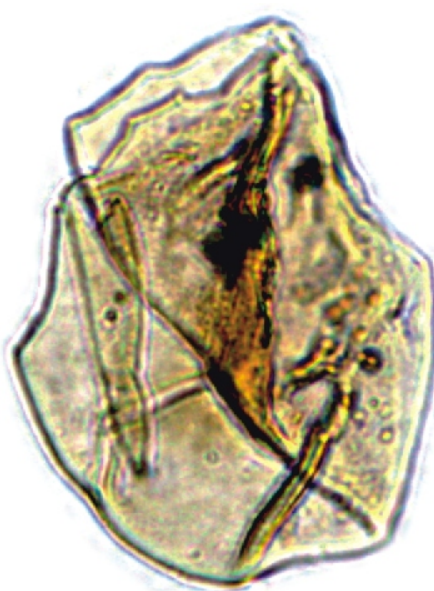

1

$50 \mu \mathrm{m}$

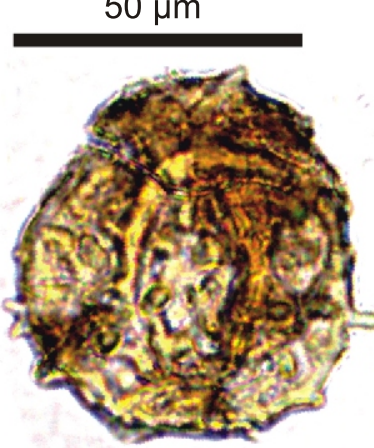

8
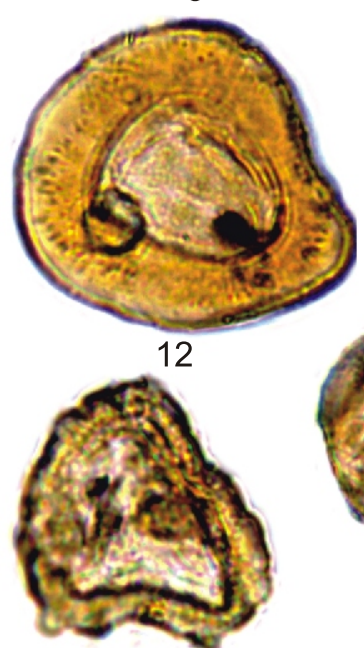

16

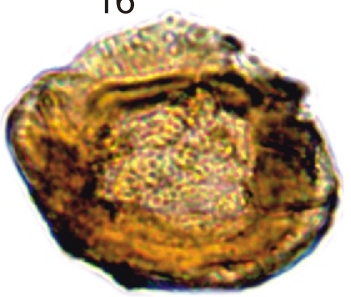

22
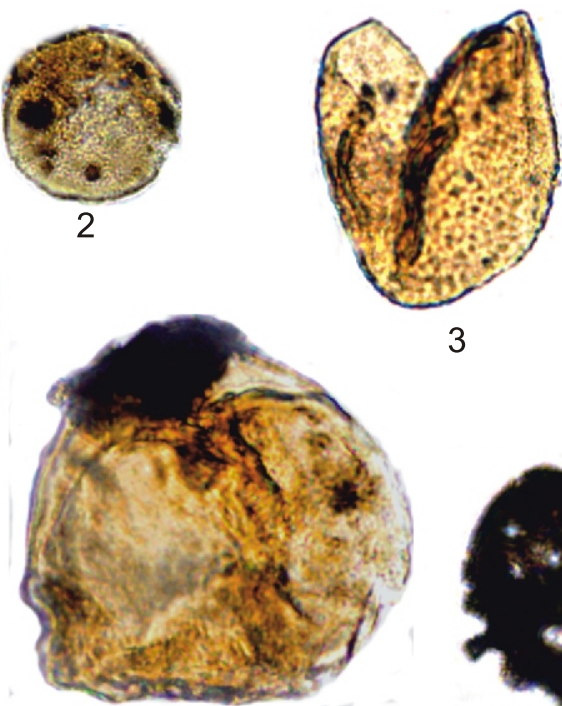

3
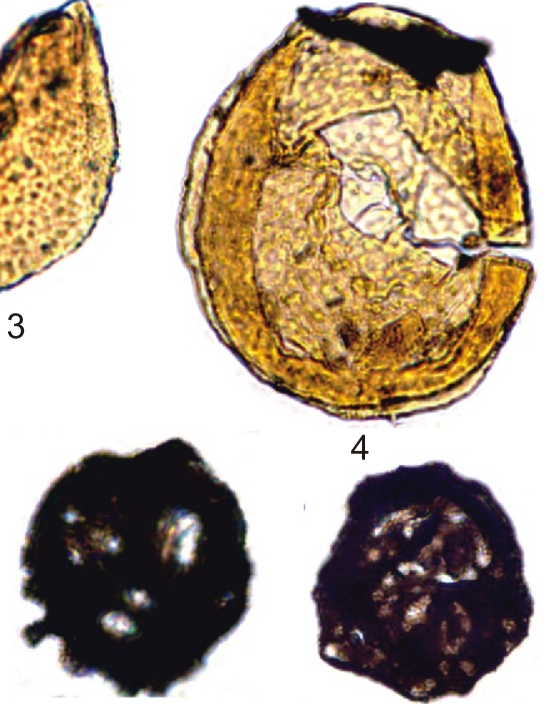

6
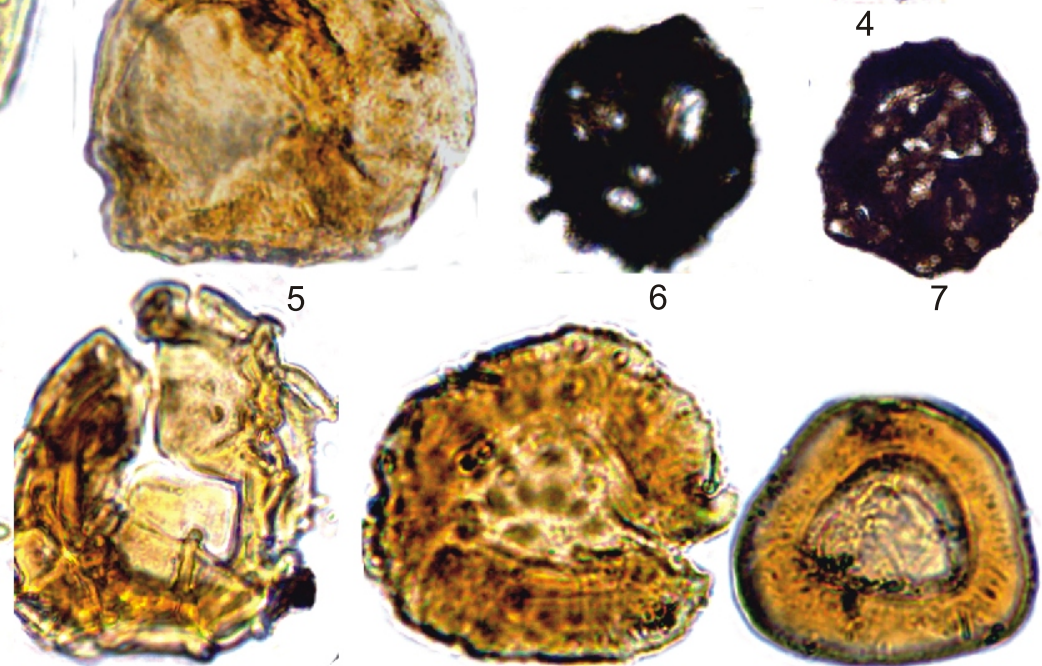

9

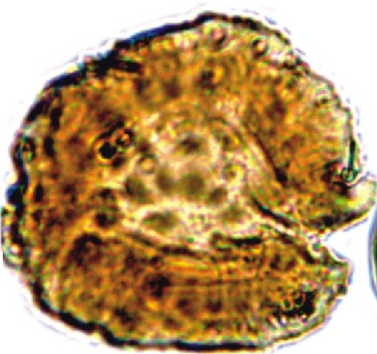

10

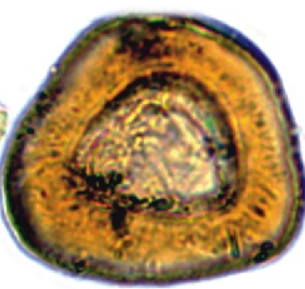

11
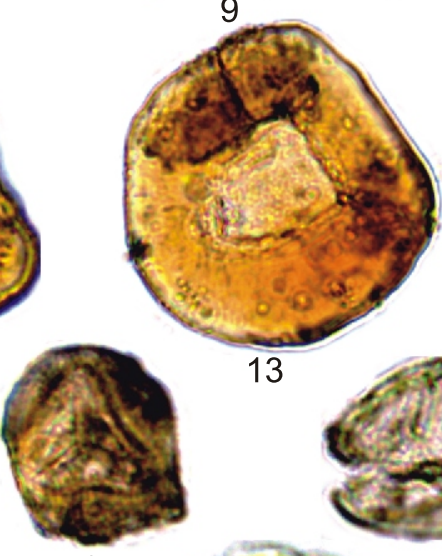

13

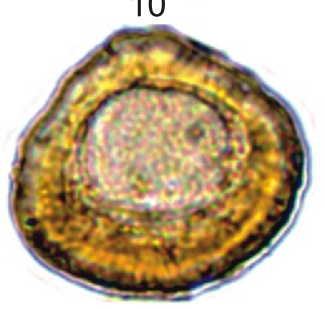

14

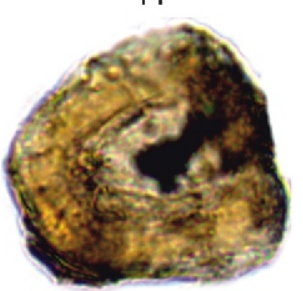

15

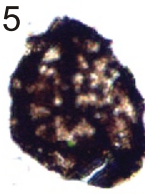

21
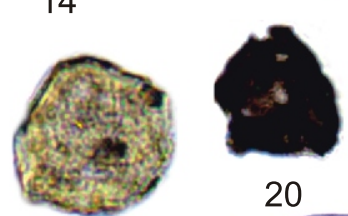

20

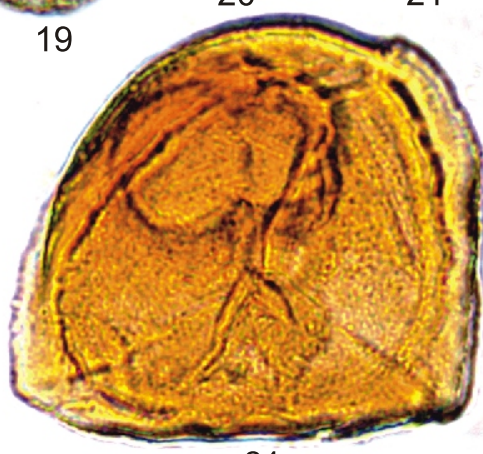

24

Fig. 6. Miospores from rocks of the Lubiechów Quarry

1 - Calamospora mutabilis, sample Lub 9, sidle 3, M 10,2; 2 - Verrucosisporites microtuberosus, sample Lub 6, slide 1, N 29,2; 3 Planisporites magnus, sample Lub 6, slide 3, M 55,3; 4 - Planisporites magnus, sample Lub 6, slide 3, Q 21,4; 5 - Cadiospora magna, sample Lub 6, slide 1, Z 24; 6 - " Knoxisporites sp., sample Lub 2, slide 2, M 54; 7 - *Bascaudaspora sp., sample Lub 9, slide 3, M 17,1; 8 Raistrickia superba, sample Lub 6, slide 2, N 12,3/O 12,1; 9 - Reticulatisporites reticulatus, sample Lub 6, slide 1, A 26,2; 10 Cristatisporites indignabundus, sample Lub 6, slide 7, J 45,3/K 45,1; 11 - Densosporites variabilis, sample Lub 6, slide 4, M 52,3; 12 Densosporites variabilis, sample Lub 6, slide 2, A 36,3; 13 -Densosporites intermedius, sample Lub 6, slide 1, C 48; 14 - Densosporites sphaerotriangularis, sample Lub 6, slide 1, Q 12,3; 15 -Densosporites triangularis, sample Lub 6, slide 1, Y 49,4; 16 - Westphalensisporites irregularis, sample Lub 9, slide 4, Z 30,3; 17 - Rotaspora knoxi, sample Lub 6, slide 6, B 42,3/C 42,1; 18 - Lycospora pusilla, sample Lub 6 , slide 2, W 3,4; 19 - Lycospora pusilla, sample Lub 6, sidle 9, R 36; 20 - 'Lycospora sp., sample Lub 9, slide 1, W 20,4/X 20,2; 21 ${ }^{*}$ Lycospora sp., sample Lub 10, slide 1, S 26,1; 22 - Cingulizonates loricatus, sample Lub 6, slide 2, Q 35,3; 23 - Cirratriradites anuliformis, sample Lub 6, slide 6, G 13,4; 24 - Cirratriradites anulatus, sample Lub 6, slide 6, P 10,1/P 10,3; * - taxon belongs to the Visean-Serpukhovian sub-assemblage 


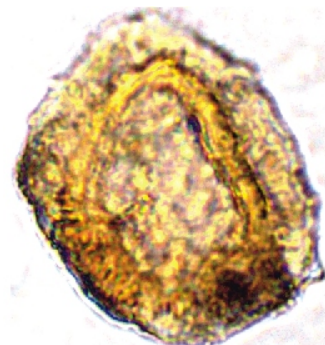

1

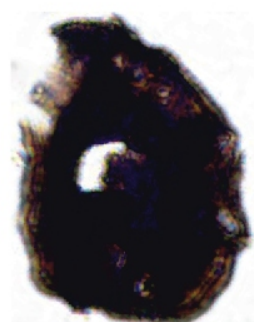

2

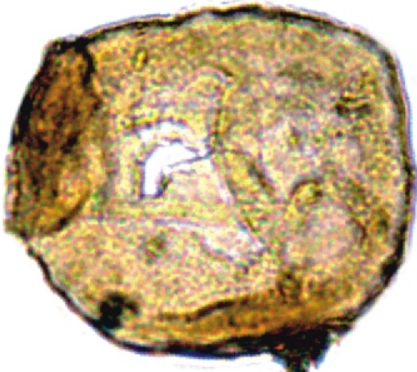

3
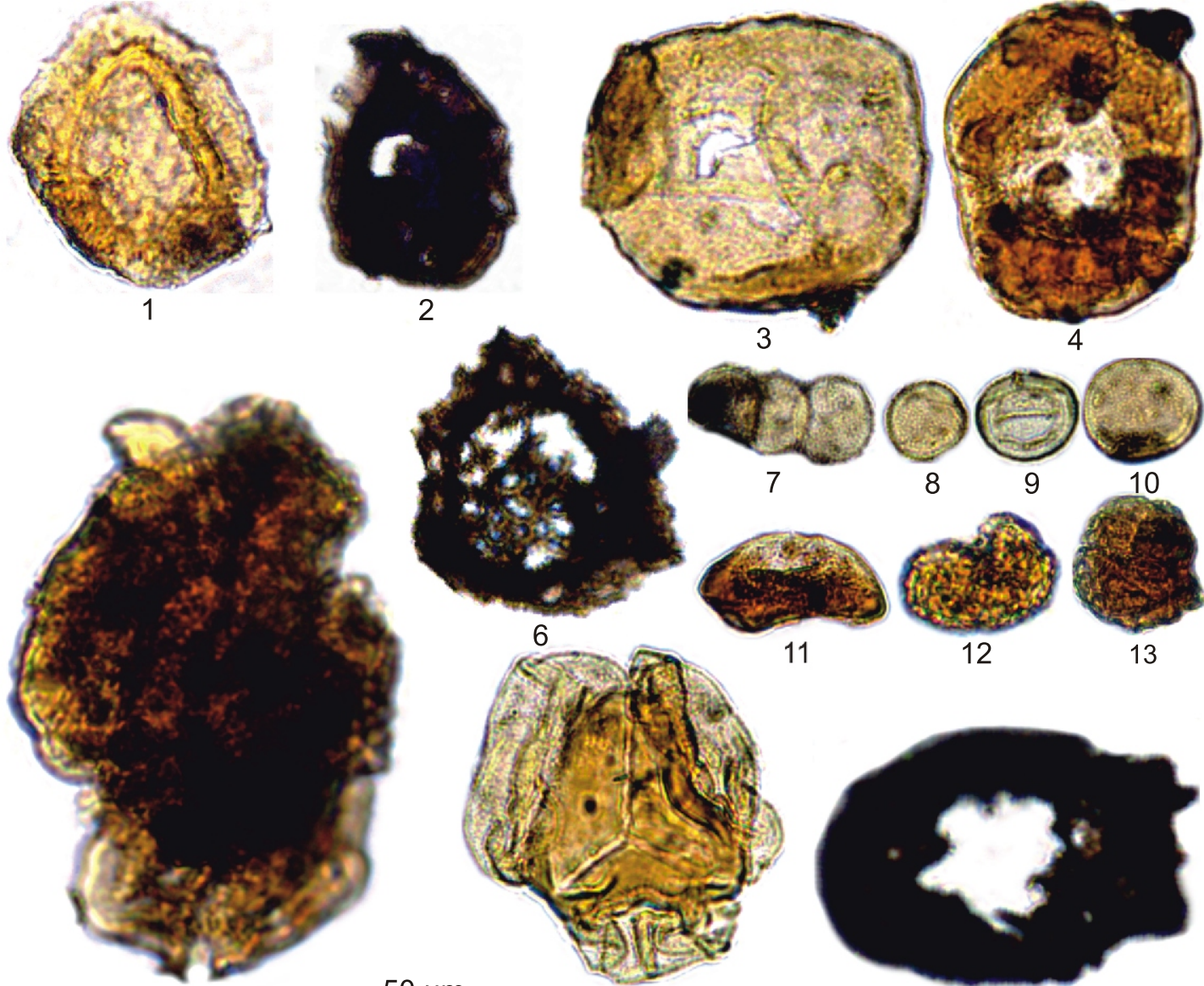

5

$50 \mu \mathrm{m}$
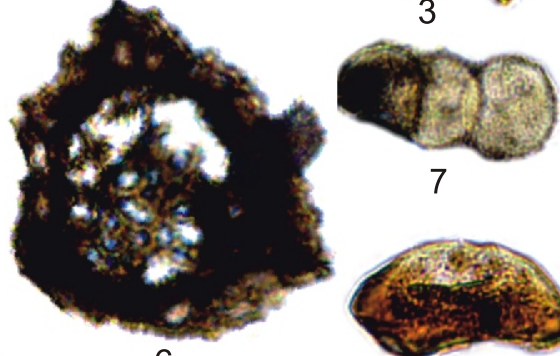

7

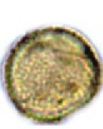

8
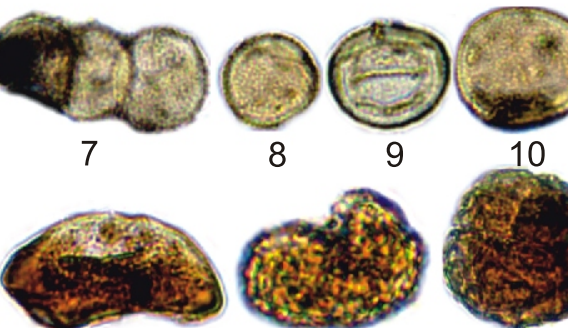

11

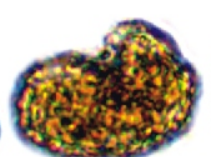

12

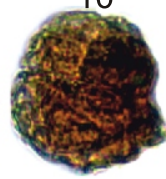

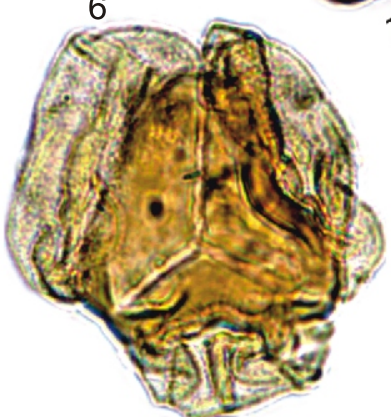

14

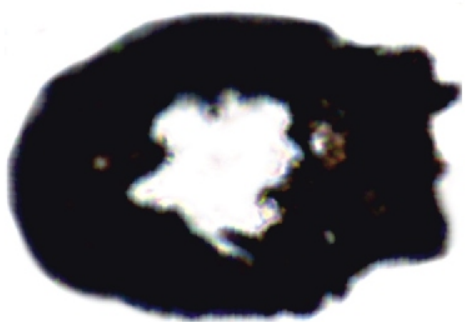

15

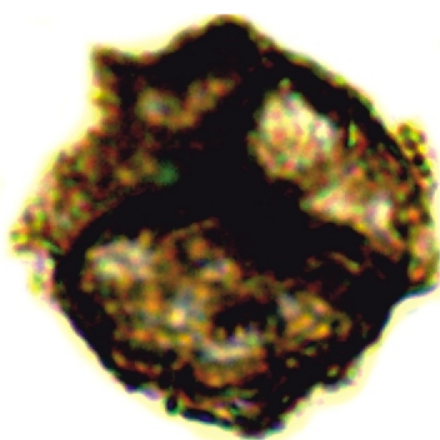

16

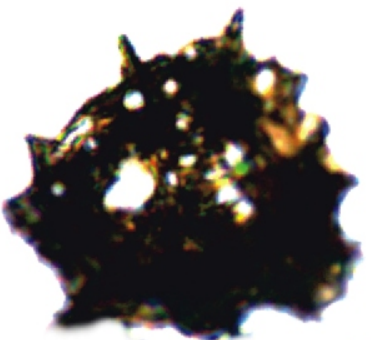

17

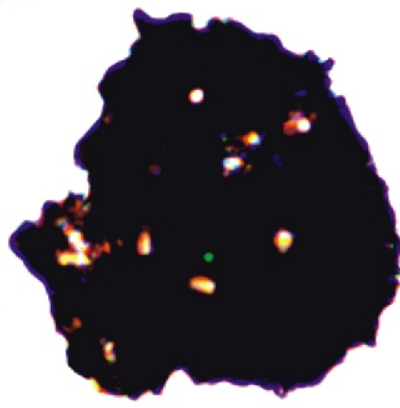

23

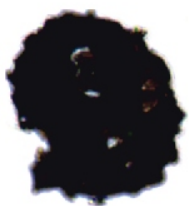

18

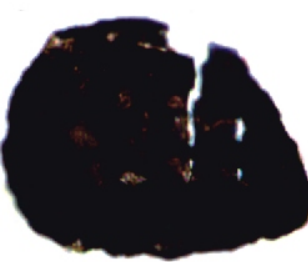

22

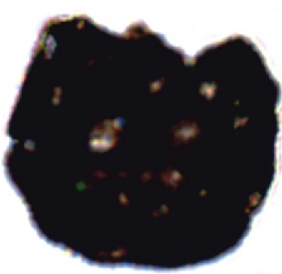

19

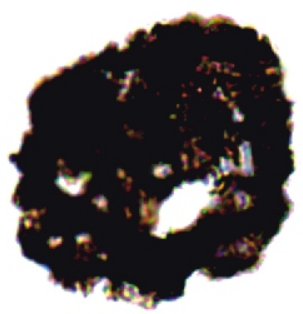

24

Fig. 7. Miospores from rocks of the Lubiechów Quarry and the outcrop near Witoszów Górny

1 - Radiizonates striatus, sample Lub 6, slide 1, P 56,1; 2 - * Radiizonates sp., sample Lub 5, slide 6, N 28,1; 3 - Crassispora kosankei, sample Lub 6, slide 4, X 45; 4 - Latensina trileta, sample Lub 9, slide 2, Z 55,1; 5 - *Kraeuselisporits sp., sample Lub 9, slide 1, Y 7; 6 *Vallatisporites sp., sample Lub onk 1, slide 1, O 12; 7 - Punctatosporits minutus, sample Lub 1, sample 1, D 34,2; 8 - Punctatosporites minutus, sample Lub 1, sample 1, D 42,4; 9 - Punctatosporites cingulatus, sample Lub 2, slide 1, M 24,1/M 24,3; 10 - Punctatosporites punctatus, sample Lub 6, slide 1, P 54,1; 11 - Torispora securis, sample Lub 9, slide 2, X 39,1; 12 - Thymospora obscura, sample Lub 9, slide 2, N 43,3; 13 - Thymospora pseudothiessenii, sample WG 6, slide 2, P 61; 14 - Alatisporites trialatus, sample Lub 6, slide 4, Z 35; 15 *Schulzospora sp., sample Lub 3 o, slide 1, Z 41,2; 16 - undetermined, sample Lub 6, slide 1, O 23,3; 17 - undetermined, sample Lub 6, slide 1, S4 0,3/T 40,1; 18 - undetermined, sample Lub 1, slide 1, T 9; 19 - *undetermined, sample Lub 9, slide 1, F 48,1; 20 - *undetermined, sample Lub 9, slide 1, Z 44,1; 21 - *undetermined, sample Lub 6, slide 1, Z 31,2; 22 - *undetermined, sample Lub 6, slide 2, N 12; 23 - *undetermined, sample Lub 9, slide 1, F 50,3; 24 - *undetermined, sample Lub 3, slide 1, R 36,2; * taxon belongs to the Visean-Serpukhovian sub-assemblage 
The important age indicator for the dark-coloured miospore sub-assemblage is the genus Lycospora. This genus, as dispersed miospore, occur in Europe in rocks not older than Visean. The occurrence of Rotaspora knoxi, a species with a relatively short stratigraphic range, limits the age of this sub-assemblage to the interval from the Raistrickia nigra-Triquitrites marginatus (NM) to Stenozonotriletes triangulus-Rotaspora knoxi (TK) palynozones, corresponding to the Late Visean and Early Serpukhovian (Clayton et al., 1977; Owens et al., 2004 Fig. 8). The analysis of stratigraphic ranges of all taxa recognized in this sub-assemblage indicates that they are of Late Visean-Serpukhovian age.

The other set of miospores is represented by well-preserved specimens of relatively light colour. Some stratigraphically important taxa were found in this sub-assemblage, allowing exact age interpretation. One of them is Lycospora, which is the most common genus of the European Carboniferous, but it occurs in rocks not older than Visean. Another important taxon is Crassispora kosankei. Its occurrence shows that this miospore sub-assemblage is not older than Serpukhovian. In turn, the presence of Reticulatisporites reticulatus indicates an age not older than Late Namurian (Owens et al., 2004). This sub-assemblage contains also younger taxa, for example Cingulizonates loricatus and the genus Punctatosporites important for the Langsettian (former Westphalian A). The first of them appeared at the beginning of the Langsettian. Slightly later, but still in the Langsettian, the genus Punctatosporites is recorded for the first time. The occurrence of Westphalensisporites irregularis and Microreticulatisporites nobilis proves that the sub-assemblage is not older than Duckmantian (Westphalian B). The youngest taxa are the monolete genera Torispora and Thymospora, as well as the species Cadiospora magna and Latensina trileta. All these taxa are characteristic for the Asturian (former Westphalian D), although Torispora appeared slightly earlier. The composition of the sub-assemblage of dispersed miospores is correlated to the miospore zone Thymospora obscura-T. thiessenii (OT), which corresponds to the Asturian (Clayton et al., 1977; Fig. 8).

\section{REMARKS ON PALAEOTEMPERATURE}

The above-presented palynological data allow the reconstruction of palaeothermal history of rocks studied based on miospore colour. This interpretation is possible, as miospores of different ages vary in colour, but, unfortunately, not all rules of thermal alteration assessment could be applied here. The miospore colour was assessed partly on the oxidized palynological material, and it was impossible to use a single miospore taxon for this purpose, so the observation was made on different taxa. These methodical modifications caused that obtained results of thermal alteration assessment should be considered approximate. The occurrence of two miospore sub-assemblages of different colours indicate their different thermal histories. The observation of dark-coloured miospores before the sample oxidation reveals that all these specimens are black. The same sub-assemblage after oxidation shows a slight difference in colour between fully black miospores from Daisy Lake near Mokrzeszów (outcrop no. 4 in Fig. 1B) and dark brown to black miospores from all remaining sites. The determination of miospores from this sub-assemblage is usually impossible. None of black miospores from Daisy Lake is determinable, but rocks from this site are dated at the Upper Devonian by macrofaunal fossils, partly in living position (Gunia 1968). Black colour of all miospores in these Devonian rocks suggests that they were heated up to $\sim 180^{\circ} \mathrm{C}$ (Batten, 1996).
The dark miospore sub-assemblage occurring in rocks included to the Upper Visean-Serpukhovian, besides of black miospores contain also some dark brown specimens. These colours indicate that the maximum palaeotemperature probably did not exceed $160-170^{\circ} \mathrm{C}$ (Batten, 1996). The observations point to two events of heating recorded in the dark-coloured miospore sub-assemblages. The first one took place between the Frasnian and late Visean. The second one was after the late Visean-Serpukhovian and before the Asturian, as miospores of this age are much lighter in colour. The yellow-orange to orange-brown colours of the Asturian miospores indicate much lower thermal alteration in a temperature not higher than $70^{\circ} \mathrm{C}$ (Batten, 1996).

\section{DISCUSSION}

The results of palynological analysis of rocks from the Świebodzice Unit provided completely new data. Rocks of the Pogorzała Formation, formerly interpreted as Devonian (Gunia, 1968), yielded a number of Carboniferous miospores. Their occurrence in these rocks indicates the Carboniferous age. This result changes the earlier views of Gunia (1968) on their Devonian age and fits well with the model of the Świebodzice Unit development presented by Wojewoda (2016a, b).

The important feature of this miospore assemblage is that it consists of two sub-assemblages of different ages and thermal histories. They were found in rocks abundant in Devonian and Carboniferous macrofossils, partly reworked, identified by previous researchers. That means that the assemblage of fossils is very complex and its stratigraphical interpretation is extremely difficult.

Taking into consideration the results of all previous and recent biostratigraphical studies from the Świebodzice Unit, a relatively long stratigraphic interval from the Late Devonian (Frasnian) to Late Pennsylvanian (Asturian) should be determined. Three shorter intervals are biostratigraphically demonstrated and they are the important dates in history of this geological unit.

The oldest interval spans the early Frasnian to Tournaisian, as proved by palaeontological evidence. The Devonian fossils (Middle Frasnian corals) were studied by Zobell and Carnall (1831), Dames (1868), Gürich (1909) and Różkowska (1962). Systematic stratigraphical studies were later conducted by Gunia (1962, 1966a, b, 1968) who determined 182 fossil taxa of Devonian marine macrofauna, mainly brachiopods and clams, also Rugosa corals and stromatoporoids. The most important fossils are ammonoids which are poorly preserved and not numerous. Gunia (1968) accepted partly Tournaisian age of the Książ conglomerates based on Lepidodendron sp. found by Zimmerman (1936). That author rejected all other Carboniferous datings and considered that the stratigraphic interval from the Early Frasnian to Tournaisian houses the entire history of the Świebodzice Unit (Gunia, 1968).

The next interval is at the Visean/Serpukhovian transition, evidenced in this paper by an assemblage of dark, poorly preserved miospores from Lubiechów and Witoszów Górny. A specimen of Adiantites antiquus (Ettingshausen) Stur, found during our field work in a rocky block in the Lubiechów Quarry (Fig. 3), may also indicate this age. A similar result was reported by Krawczyńska-Grocholska (1973) from the Chwaliszów area where a mixed miospore assemblage was found. There are some previous Carboniferous datings, based on fossil macroflora and marine fauna, and they probably also belong to this stratigraphic interval. They originate from the vicinity of Witoszów Górny, where fossil clams Posidonia becheri, 


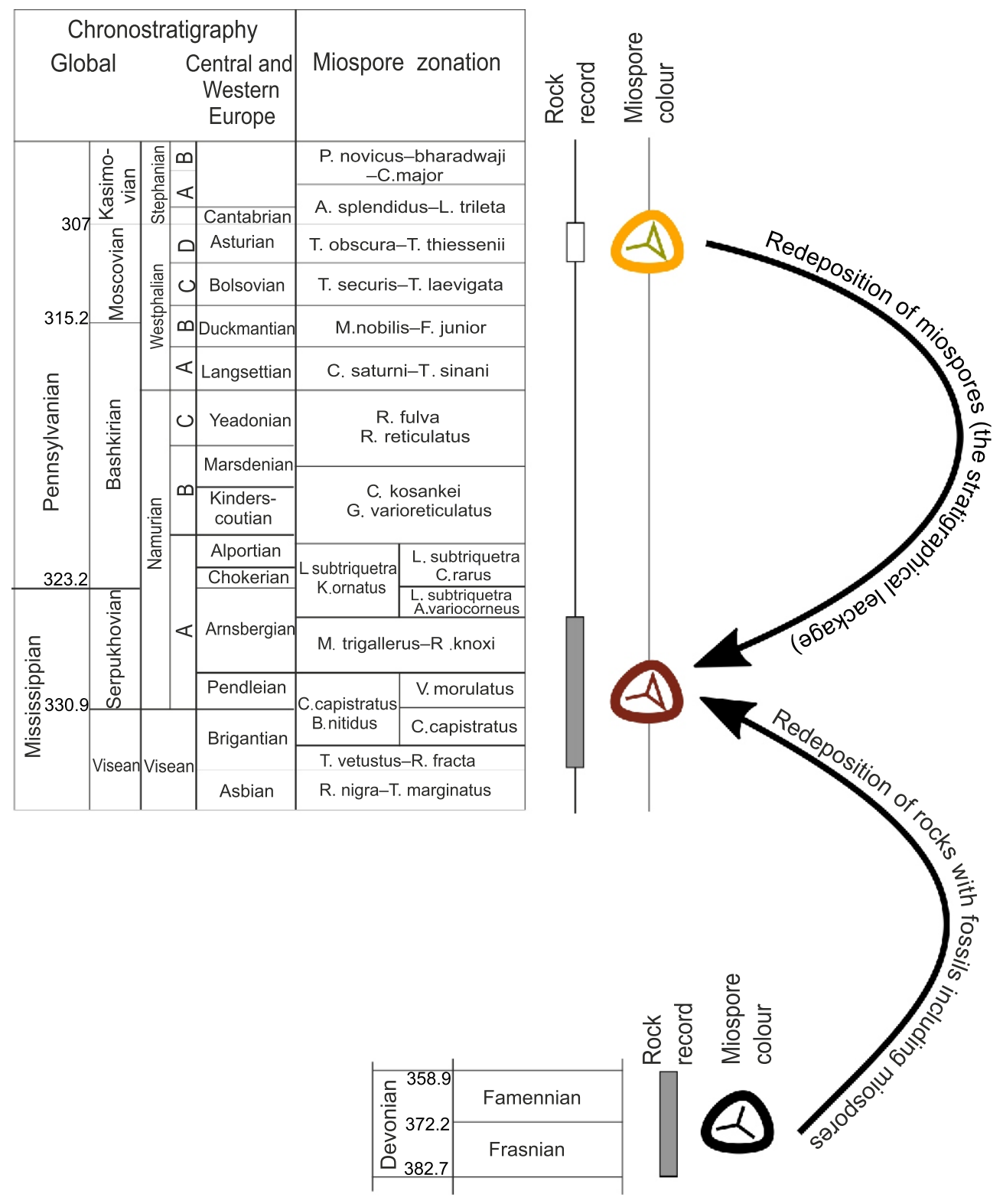

Fig. 8. Stratigraphic scheme of the Pogorzała Formation from the southern part of the Świebodzice Unit (miospore zonation of the Carboniferous in Europe according to Clayton et al., 1977 and Owens et al., 2004)

Edmondia and Protoschizodus were found in slate roof tiles (Dames, 1868; Bederke, 1924). Some typically Carboniferous taxa of macroflora: Mesocamites roemeri (Goeppert) Hirmer, Calamites tenuissimus Goeppert and Sigillaria minutissima Goeppert were recognized from the same quarry (Cramer et al., 1924). Zimmermann (1936) completed the list of identified flora by Rhodea zygopteris and Lepidodendron sp. Some Carboniferous plant specimens from the vicinity of Mokrzeszów are in the collection of the Geological Museum of the University of Wrocław, including Ulodendron subdiscophorum Weiss et Sterzel (catalog no. 287p) and Asterocalamites scrobiculatus (Brongniart) Zeiller (catalog no. 6374p). Unfortunately, their origin and exact location are unknown. None of these Carboniferous datings were taken into account by Gunia (1968).

The great surprise is, however, the palynostratigraphical result indicating the Asturian age, which is evidenced by well-preserved, light-coloured miospores found in the Pogorzała For- mation rocks. This is the third important date in the history of the Świebodzice Unit, which had not been known earlier.

The significance of each of these three dates is not obvious and requires discussion. The occurrence of dispersed Carboniferous miospores is crucial in the context of Carboniferous age of studied rocks, but the miospore assemblages indicate two Carboniferous dates. The application of classical rules of stratigraphic interpretation would lead to the conclusion on the Asturian age of discussed rocks, as miospores of this age are the youngest fossils. However, such a statement seems to be doubtful because Asturian miospores are very rare in the studied rocks. They were found only in seven out of nearly fifty samples and their frequency in these productive samples is uneven. Distribution of samples containing Asturian miospores in the Lubiechów Quarry (Fig. 2C, D) and the Witoszów Górny outcrop (Fig. 5B) is irregular and chaotic, and cannot be explained by processes from time of sedimentation. 
The sub-assemblage of dark miospores occurs in all studied rocks, so it is more convenient for the stratigraphic purpose although these miospores are very poorly preserved. They indicate the Late Visean-Serpukhovian age that is considered the age of the studied Pogorzała Formation rocks. This conclusion integrates well the rocks into the palaeogeographical situation and allows the correlation with rocks occurring in neighbouring geological units - the Intrasudetic Basin and the Bardo Unit (Górecka-Nowak and Muszer, 2011). According to this stratigraphic interpretation, all Devonian fossils in the Świebodzice Unit should be considered reworked; however, the occurrence of Asturian miospores also requires elucidation.

Redeposition of Devonian macrofossils has been known for a very long time. Reworked macrofossils were described and determined from limestone pebbles occurring in the Upper Frasnian conglomerates (Gunia, 1962, 1966a, b, 1968). All remaining Devonian macrofossils were considered coeval with the rocks and stratigraphically important (Gunia, 1962, 1966a, b, 1968). Actually, the degree of macrofossil reworking is difficult to estimate. Reworked macrofossils probably occur also in larger blocks and olistoliths, as described specimens of Devonian benthic macrofauna are found in living position (Halamski, 2013). Our observations of rocks from the Lubiechów Quarry suggest that probably at least part of the Devonian fossils in mudstones of the Pogorzała Formation are also reworked. It would elucidate the reason of some previous contradictory biostratigraphical interpretations, although this topic requires further studies on macrofossils to elucidate their stratigraphic significance, and make a revision of previous results.

The occurrence of the Asturian miospores in rocks dated as Visean/Serpukhovian may be explained by their migration in water which has penetrated already consolidated rocks of the Pogorzała Formation. The water might use tectonic cracks which are very common in rocks from the Lubiechów Quarry and the outcrop near Witoszów Górny. This phenomenon is called the stratigraphical leakage (Wilson, 1964; Streel and Bless, 1980) and elucidates irregular distribution of Asturian miospores in studied rocks. Similar cases that older rocks are contaminated by younger microfossils, mainly miospores, were described from many localities (e.g., Guennel, 1963 Steemans, 1995). Undoubtedly, the presence of the Asturian miospores is a record of the final stage of the Swiebodzice Unit development, when this area was already uplifted. On its surface sedimentation in the continental conditions took place. Miospores found in the studied rocks originated from sediments deposited then and eroded later. This Asturian stage of the Świebodzice Unit history was during the Late Variscan vol- cano-magmatic activity (Awdankiewicz and Kryza, 2010; Kryza and Awdankiewicz, 2012; Turniak et al., 2014).

Assemblages of fossils discussed in this paper resemble similar assemblages found in the Carboniferous succession from the basement of the Fore-Sudetic Homocline. They are also considered as mixed with great participation of reworked fossils. In both cases miospore data allowed proper stratigraphic interpretation, terminating long-standing controversy (Górecka-Nowak, 2007, 2008, 2009, 2010; Mazur et al., 2010).

New miospore data prove that geological history of the Świebodzice Unit was more complex than previously assumed. Results presented in this paper indicate that this geological unit urgently requires new multidisciplinary geological studies to elucidate its geological setting, stratigraphy and relations to the neighbouring units.

\section{CONCLUSIONS}

Results of the palynostratigraphical studies of the Pogorzała Formation from the southern part of the Świebodzice Unit clearly indicate the Carboniferous age of rocks which were regarded before as Devonian based on marine fossils (Gunia, 1968). The miospore assemblage found in these rocks is mixed. It consists of two sub-assemblages of different colours and ages. The rocks are considered late Visean/Serpukhovian in age. All older rocks and fossils found in these rocks are redeposited. The occurrence of Asturian miospores in the Visean-Serpukhovian rocks is a result of miospore redeposition of stratigraphic leakage type (Fig. 8). Observations of miospore colours indicate that the thermal event, which occurred before Asturian and probably in two stages. The first one was after the Late Devonian and before the Late Visean-Serpukhovian, and the palaeotemperature exceeded $\sim 180^{\circ} \mathrm{C}$ at that time. The second stage was after the Serpukhovian and before the Asturian, and the palaeotemperature was not higher than $160-170^{\circ} \mathrm{C}$. The results of this palaeothermal analysis confirm that rocks filling the Świebodzice Unit are synorogenic.

Acknowledgements. Our studies were supported by a grant of the University of Wrocław 1017/S/ING/16-4. We are grateful to the reviewers, J. Bek (Czech Academy of Sciences) and P. Filipiak (University of Silesia, Poland), as well as to an anonymous reviewer for their constructive comments that allowed improving this paper.

\section{REFERENCES}

Awdankiewicz, M., Kryza, R., 2010. The Chełmiec subvolcanic intrusion (Intrasudetic Basin, SW Poland): preliminary SHRIMP zircon age. Mineralogia Special Papers, 37: 69.

Batten, D.J., 1996. Chapter 26B. Palynofacies and petroleum potential. American Association of Stratigraphic Palynologists Foundation, 3: 1065-1084.

Bederke, E., 1924. Das Devon in Schlesien und das Alter der Sudetenfaltung. Fortschritte der Geologie und Palaeontologie, 7: 1-50.

Berg, G., Dathe, E., Zimmermann, E., 1910. Geologische Karte von Preussen und Benachbarten Bundesstaaten, 1:25000. Blatt Friedland in Schlesien, Berlin.
Bröcker, M., Żelaźniewicz, A., Enders, M., 1998. Rb-Sr and U-Pb geochronology of migmatitic layers from the Góry Sowie (West Sudetes, Poland): the importance of Mid-Late Devonian metamorphism. Journal of the Geological Society, 155: 1025-1036.

Chorowska, M., 1978. Visean limestones in the metamorphic complex of the Kaczawa Mts. (Sudetes) (in Polish with English summary). Annales Societatis Geologorum Poloniae, 48: 245-261.

Clayton, G., Coquel, R., Doubinger, J., Gueinn, K.J., Loboziak, S., Owens, B., Streel, M., 1977. Carboniferous miospores of Western Europe: illustration and zonation. Mededelingen Rijks Geologische Dienst, 29: 1-71. 
Cramer, R., Finckh, L., Zimmermann, E., 1924. Erläuterungen zur geologische Karte, Blatt Schweidnitz: 3-51. Berlin.

Dames, E. 1868. Über die in der Umgebung Freiburgs in Nieder-Schlesien auftretenden devonischen Ablagerrungen. Zeitschrift der Deutschen Geologischen Gesellschaft, 20: 469-508.

Górecka-Nowak, A., 2007. Palynological constrains on the age of Carboniferous clastic succession of western Poland. Geological Quarterly, 51 (1): 39-56.

Górecka-Nowak, A., 2008. New interpretations of the Carboniferous stratigraphy of SW Poland based on miospore data. Bulletin of Geosciences, 83: 101-116.

Górecka-Nowak, A., 2009. Palynological data from the Siciny IG 1 and Marcinki IG 1 boreholes and their significance in the recognition of the Carboniferous succession of SW Poland. Geological Quarterly, 53 (2): 167-186.

Górecka-Nowak, A., 2010. Complementary data on the palynostratigraphy of the Carboniferous succession of SW Poland. Geological Quarterly, 54 (3): 337-356.

Górecka-Nowak, A., Muszer, J., 2011. Palynology of the upper Visean Paprotnia Beds (Bardo Unit, Polish Sudetes). Geological Quarterly, 55 (2): 165-180.

Guennel, G.K., 1963. Devonian spores in a Middle Silurian reef. Grana Palynologica, 4: 245-261.

Gunia, T., 1962. Fauna and age of limestone pebbles from the Culm of Książ (in Polish with English summary). Rocznik Polskiego Towarzystwa Geologicznego, 34: 493-523.

Gunia, T., 1966a. Fauna and age of limestone pebbles from the Culm of Książ (in Polish with English summary). Geologia Sudetica, 2: 297-321.

Gunia, T., 1966b. New investigations of the stratigraphy and paleogeography of the Upper Devonian of the Świebodzice Unit (in Polish with English summary). Z Geologii Ziem Zachodnich: 169-183.

Gunia, T., 1968. On the fauna, stratigraphy and conditions of sedimentation of the Upper Devonian in the Świebodzice depression (Middle Sudetes) (in Polish with English summary). Geologia Sudetica, 4: 115-220.

Gunia, T., 1985. Geological position of the Sowie Góry block and its influence on the paleogeography of the Paleozoic of Centra Sudetes (in Polish with English summary). Geologia Sudetica, 20: 83-119.

Gürich, G., 1909. Clymenienkalk von der Conradmühle in Polsnitz bei Freiburg in Schlesien. Abhandlungen der Preussischen Geologischen Landesanstalt, 30: 341-344.

Halamski, A.T., 2013. Frasnian Atrypida (Brachiopoda) from Silesia (Poland) and the age of the eo-Variscan collision in the Sudetes. Geodiversitas, 35: 289-308.

Kaczorowski, M., Wojewoda, J., 2011. Neotectonic activity interpreted from a long water-tube tiltmeter record at the SRC geodynamic laboratory in Książ, Central Sudetes, SW Poland. Acta Geodynamica et Geomaterialia, 8: 1-13.

Krawczyńska-Grocholska, H., 1973. Sporomorph assemblage in sandstone and siltstone samples from Chwaliszów in the Świebodzice Dpression (Central Sudetes) (in Polish with English summary). Biuletyn Instytutu Geologicznego, 264: 211-222.

Kryza, R., Awdankiewicz, M., 2012. Ambiguous geological position of Carboniferous rhyodacites in the Intra-Sudetic Basin (SW Poland) clarified by SHRIMP zircon ages. Geological Quarterly, 56 (1): 55-66.

Mazur, S., Aleksandrowski, P., Kryza, R., Oberc-Dziedzic, T., 2006. The Variscian Orogeny in Poland. Geological Quarterly, 50 (1): 89-118.

Mazur, S., Aleksandrowski, P., Turniak, K., Krzemiński, L., Mastalerz, K., Górecka-Nowak, A., Kurowski, L., Krzywiec, P., Żelaźniewicz, A., Fanning, M.C., 2010. Uplift and late orogenic deformation of the Central European Variscan belt as revealed by sediment provenance and structural record in the Carboniferous foreland basin of western Poland. International Journal of Earth Sciences, 99: 47-64.

Nemec, W., Porębski, S.J., Steel, R.J. 1980. Texture and structure of resedimented conglomerates: examples from Książ Forma- tion (Famennian-Tournaisian), southwestern Poland. Sedimentology, 27: 519-538.

Owens, B., McLean, D., Bodman, D., 2004. A revised palynozonation of British Namurian deposits and comparisons with Eastern Europe. Micropaleontology, 50: 89-103.

Peryt, T., 1981. Phanerozoic oncoids - an overview. Facies, 4: $197-214$.

Pia, J., von 1937. Die Wichtigsten Kalkalgen des Jungpaläozoikums und ihre Geologische Bedeutung. Deuxiéme Congres pour l'Avancement des Études de Stratigraphie Carbonifere, 2: 765-856.

Pluta, K., 2012. Environment and conditions of sedimentation of Upper Devonian oncoid layers from Świebodzice depression (in Polish with English summary). MSc. thesis, Wydział Nauk o Ziemi i Kształtowania Środowiska, Uniwersytet Wrocławski.

Pluta, K., 2016. Onkoidy w depresji Świebodzic - zapis kryzysu biotycznego na przełomie fran/famen (in Polish). In: VI Polska Konferencja Sedymentologiczna POKOS 6 - „Granice Sedymentologii" 28.06-01.07.2016, Chęciny-Rzepka (eds. D. Olszewska-Nejbert, A. Filipek, M. Bąbel and A. Wysocka): 169-170.

Porębski, S.J., 1981. Świebodzice succession (Upper Devonian-lowest Carboniferous): a prograding mass flow dominated fan-delta complex (in Polish with English summary). Geologia Sudetica, 16: 101-192.

Porębski, S.J., 1984. Clast size and bed thickness trends in resedimented conglomerates: example from a Devonian fan-delta succession, southwest Poland. Canadian Society of Petroleum Geologists, Memoir, 10: 399-411.

Porębski, S.J., 1987. Środowisko depozycyjne i wpływ tektoniki na sedymentację dewonu-karbonu w depresji Świebodzic (in Polish). Przewodnik LVIII Zjazdu PTG, Wałbrzych: 114-130.

Porębski, S.J., 1990. Onset of coarse clastic sedimentation in the Variscan realm of the Sudetes (SW Poland): an example from the Upper Devonian-Lower Carboniferous Świebodzice succession. Neues Jahrbuch für Geologie und Paläontologie Abhandlungen, 179: 259-274.

Różkowska, M., 1962. The Devonian coral limestones by the Daisy Lake of Mokrzeszów (in Polish with English summary). Biuletyn Informacyjny Polskiego Towarzystwa Miłośników Nauk o Ziemi: 3-5.

Schindewolf, O.H., 1925. Einige Bemerkungen über das Sphaerocodien-Konglomerat von Alt-Liebichau bei Freiburg in Niederschlesien. Zeitschrift der Deutschen Geologischen Gesellschaft, 77: 84-95.

Steemans, P., 1995. Silurian and Lower Emsian spores in Saudi Arabia. Review of Palaeobotany and Palynology, 89: 91-104.

Streel, M., Bless, M., 1980. Occurrence and significance of reworked palynomorphs. Mededelingen Rijks Geologische Dienst, 32: 69-80.

Teisseyre, H., 1948. Sprawozdanie $z$ prac geologicznych wykonanych w Sudetach w r. 1947 (in Polish). Badania fizjograficzne nad Polską Zachodnią, 1: 6-47.

Teisseyre, H., 1952. Geological structure of the northern region of Wałbrzych (in Polish with English summary). Biuletyn Instytutu Geologicznego, 62: 5-58.

Teisseyre, H., 1956a. Świebodzice Depression as a geological unit (in Polish with English summary). Biuletyn Instytutu Geologicznego, 106: 5-36.

Teisseyre, H., 1956b. Sedimentation of the Upper Devonian of Pogorzała and Witoszów (Middle-Sudetes) (in Polish with English summary). Acta Geologica Polonica, 6: 227-251.

Teisseyre, H., 1968. Stratigraphy and tectonics of the Świebodzice depression. Biuletyn Instytutu Geologicznego, 222: 71-106.

Teisseyre, H., Smulikowski, K., Oberc, J., 1957. Geologia Regionalna Polski (in Polish). Tom III, 1: 1-300.

Timmermann, H., Parrish, R.R., Noble, S.R., Kryza, R., 2000. New U-Pb monazite and zircon data from the Sudetes Mountains in SW Poland: evidence for a single-cycle Variscan orogeny. Journal of the Geological Society, 157: 265-268.

Turniak, K., Mazur, S., Domańska-Siuda, J., Szuszkiewicz, A., 2014. SHRIMP U-Pb zircon dating for granitoids from the 
Strzegom-Sobótka Massif, SW Poland: Constraints on the initial time of Permo-Mesozoic lithosphere thinning beneath Central Europe. Lithos, 208: 415-429.

Urbanek, Z., 1975. On the occurrence of Upper Devonian rocks in the epimetamorphic complex of the Kaczawa Mts. (Western Sudetes). Bulletin de I'Academie Polonaise des Sciences de la Terre, 22: 167-172.

Urbanek, Z., 1978. The significance of the Devonian conodont faunas for the stratigraphy of the epi-metamorphic rocks of north-eastern part of the Góry Kaczawskie. Geologia Sudetica, 13: 7-27.

Van Breemen, O., Bowes, D.R., Aftalion, M., Żelaźniewicz, A. 1988. Devonian tectonothermal activity in the Sowie Góry gneissic block, Sudetes, SW Poland: evidence from $\mathrm{Rb}-\mathrm{Sr}$ and $\mathrm{U}-\mathrm{Pb}$ isotopic studies. Annales Societatis Geologorum Poloniae, 58: 3-19.

Wilson, L.R., 1964. Recycling, stratigraphic leakage and faulty techniques in palynology. Grana Palynologica, 5: 425-436.

Wojewoda, J., 2014. Świebodzice Unit revisited - kinematic, structural and facial evolution till now. Abstracts of 15th Czech-Polish Workshop on Recent Geodynamics of the Sudetes and the Adjacent Areas, Karlov pod Pradedem: 63-64.

Wojewoda, J., 2016a. Basen świebodzki - granice, architektura osadów i ewolucja strukturalna (in Polish). In: VI Polska Konferencja Sedymentologiczna POKOS 6 - „Granice Sedymentologii” 28.06-01.07.2016, Chęciny-Rzepka (eds. D
Olszewska-Nejbert, A. Filipek, M. Bąbel and A. Wysocka): 142-144.

Wojewoda, J., 2016b. About the need to develop the second edition of the detailed geological map of the Sudetes at the scale of $1: 25,000$ - examples of a revision of the geological pattern using the LIDAR Digital Elevation Models (in Polish with English summary). Przegląd Geologiczny, 64: 597-603.

Zimmermann, E., 1911. Konglomerat mit Sphaerocodium und Spirifer verneuili aus dem Kalkgraben bei Liebichau unweit Freiburg in Schlesien. Zeitschrift der Deutschen Geologischen Gesellschaft, 63: 35-36.

Zimmermann, F., 1936. Das Alter der Gneiskonglomerate des Fürstensteiner Kulms. Jahrbuch der Preussischen Geologischen Landesanstalt, 56: 205-207.

Zinkiewicz, J., 1973. Absolute age determination of rocks by $\mathrm{Rb}-\mathrm{Sr}$ method (in Polish with English summary). Przegląd Geologiczny, 21: 251-254.

Zobel, J., Carnall, R., 1832, Geognostische Beschreibung von einem Theile des Nieder-Schlesischen, Glätzischen und Böhmischen Gebirges. Archiv für Mineralogie, Geognosie, Bergbau und Hüttenkunde, 4: 3-173.

Żelaźniewicz, A., Aleksandrowski, P., Buła, Z., Karnkowski, P.H., Konon, A., Oszczypko, N., Ślączka, A., Żaba, J., Żytko, K., 2011. Regionalizacja tektoniczna Polski. Komitet Nauk Geologicznych PAN: 1-60. 